\title{
Pressure ulcers in the adult intensive care unit: a literature review of patient risk factors and risk assessment scales
}

\author{
Nahla Tayyib, Fiona Coyer, Peter Lewis \\ School of Nursing, Queensland University of Technology, Queensland, Australia
}

Correspondence: Nahla Tayyib. Address: School of Nursing, Queensland University of Technology, Victoria Park Rd, Kelvin Grove, Queensland, Australia 4059. Telephone: 61-423-529-438. Email: nahla.tayyib@student.qut.edu.au.

Received: November 29, 2012

DOI : $10.5430 /$ jnep.v3n11p28

Accepted: February 20, $2013 \quad$ Online Published: April 15, 2013

URL: http://dx.doi.org/10.5430/jnep.v3n11p28

\section{Abstract}

Background: Critically ill patients are at high risk for pressure ulcer (PrU) development due to their high acuity and the invasive nature of the multiple interventions and therapies they receive. With reported incidence rates of PrU development in the adult critical care population as high as $56 \%$, the identification of patients at high risk of PrU development is essential. This paper will explore the association between PrU development and risk factors. It will also explore PrU development and the use of risk assessment scales for critically ill patients in adult intensive care units.

Method: A literature search from 2000 to 2012 using the CINHAL, Cochrane Library, EBSCOHost, Medline (via EBSCOHost), PubMed, ProQuest and Google Scholar databases was conducted. Key words used were: pressure ulcer/s; pressure sore/s; decubitus ulcer/s; bed sore/s; critical care; intensive care; critical illness; prevalence; incidence; prevention; management; risk factor; risk assessment scale.

Results: Nineteen articles were included in this review; eight studies addressing PrU risk factors, eight studies addressing risk assessment scales and three studies overlapping both. Results from the studies reviewed identified 28 intrinsic and extrinsic risk factors which may lead to PrU development. Development of a risk factor prediction model in this patient population, although beneficial, appears problematic due to many issues such as diverse diagnoses and subsequent patient needs. Additionally, several risk assessment instruments have been developed for early screening of patients at higher risk of developing PrU in the ICU. No existing risk assessment scales are valid for identification high risk critically ill patient, with the majority of scales potentially over-predicting patients at risk for $\operatorname{PrU}$ development.

Conclusion: Research studies to inform the risk factors for potential pressure ulcer development are inconsistent. Additionally, there is no consistent or clear evidence which demonstrates any scale to better or more effective than another when used to identify the patients at risk for PrU development. Furthermore robust research is needed to identify the risk factors and develop valid scales for measuring the risk of PrU development in ICU.

\section{Key words}

Pressure ulcer, Pressure ulcer risk, Risk factors, Risk assessment, Adult intensive care, Literature review 


\section{I ntroduction}

A pressure ulcer $(\mathrm{PrU})$ can occur anywhere on the body where there is prolonged exposure to pressure. Prolonged pressure (from lying or sitting on a specific part of the body) will impede capillary blood supply to an area and thus limit the delivery of oxygen and nutrients to tissue, placing patients at risk for skin breakdown ${ }^{[1]}$. Expected capillary pressure ranges are between 10 and $30 \mathrm{mmHg}{ }^{[2]}$. Tissue hypo-perfusion occurs when the interface pressure exceeds capillary pressure $^{[3,4]}$, thus increasing the likelihood of PrU development.

The epidemiology of PrU varies appreciably by clinical setting. In acute care settings PrU incidence ranges from $0.4 \%$ to $38 \%$, in long term care setting from $2.2 \%$ to $39.4 \%$, in the home care environment from $0 \%$ to $17 \%$. According to the National Healing Corporation (2005), the worldwide incidence of $\mathrm{PrU}$ in intensive care units (ICU) ranged widely from $1 \%-56 \%{ }^{[5,6]}$. Further, there is wide variation reported in PrU prevalence in ICUs between countries and continents: $49 \%$ across Western Europe ${ }^{[7]}, 22 \%$ in North America ${ }^{[7,8]}, 50 \%$ in Australia ${ }^{[9,10]}$ and $29 \%$ in Jordan ${ }^{[11]}$.

Prevalence is the most commonly reported measure of PrU largely because this is a simple and cost effective method of data collection. However, it is recognized that prevalence data is a snapshot and not a true reflection of the scope of a given problem ${ }^{[12]}$. Incidence data provides a more accurate picture of the magnitude of a problem. However, incidence data presents problems with lengthy and time consuming data collection ${ }^{[12]}$. Critically ill patients in ICU are considered to be at greatest risk for PrU development, as this patient group is likely to present with high acuity, may require mechanical ventilation and subsequent administration of sedation and pharmacological drugs potentially reducing peripheral circulation and be immobile ${ }^{[13,14]}$.

According to Vollman, the negative impact of patient immobility is directly related to the adverse event of PrU development and subsequent undesirable long-term implications such as reduction in quality of life, pain, increased medical costs, and increased mortality and morbidity rates and increase in ICU length of stay ${ }^{[14]}$. In addition to these consequences of PrU, the financial impact of treatment should be considered including cost to healthcare system and also personal cost to patients. Worldwide PrU treatment costs to healthcare systems are a significant burden. The annual cost is approximately $£ 1.4-£ 2.1$ billion in the UK ${ }^{[15]}$ and $\$ 1.6$ billion in the US for the treatment of pressure ulcers ${ }^{[16]}$. In Australia, pressure ulcer costs have been identified as $\$ 18,964$ per each critically ill patient ${ }^{[17]}$. In the UK, the cost of PrU was four per cent of total healthcare expenditure ${ }^{[15]}$. These adverse outcomes emphasize the importance of preventing PrU. While PrU has been extensively examined in the literature only one review addresses this issue in the context of ICU. Given this paper was published in 2002 and the literature included in the review was published between 1980and 1999; a further review of PrU in the ICU environment is timely.

\section{Aims}

The aim of this paper is to review existing literature to explore the association between PrU development and risk factors. The paper also aims to examine PrU risk assessment scales for critically ill patients managed in adult intensive care units.

\section{Method}

A comprehensive search of databases and Internet research engines holding information related to PrU in intensive care units was conducted. PrU was defined and classified according to NPUAP/EPUAP guidelines ${ }^{[18]}$. The CINHAL; Cochrane Library; EBSCOHost; Medline (via EBSCOHost); PubMed; ProQuest databases were searched along with Google scholar search engine from 2000 to 2012. The key search terms entered into database searches were: pressure ulcer; pressure sore; decubitus ulcer; bed sore; critical care, intensive care; critical illness; prevalence and incidence; prevention; management; risk factor; risk assessment scale. Databases were searched for relevant information contained within journals, books, handbooks and abstracts. Literature searches were limited by language (English). The criteria used for article selection were 1) quantitative studies; 2) studies related to risk factors of pressure ulcer development; 3) studies 
of adult patients; 4) studies specific to the intensive care environment; and 5) studies that contained a sub-analysis of results specific to the adult intensive care setting. The reference list of each selected article was also checked manually as a source of additional information. A total of 28 original studies were reviewed. Following this initial review eight papers were excluded as they failed to meet the above inclusion criteria. A total of 19 articles are included in this review (see Figure 1).
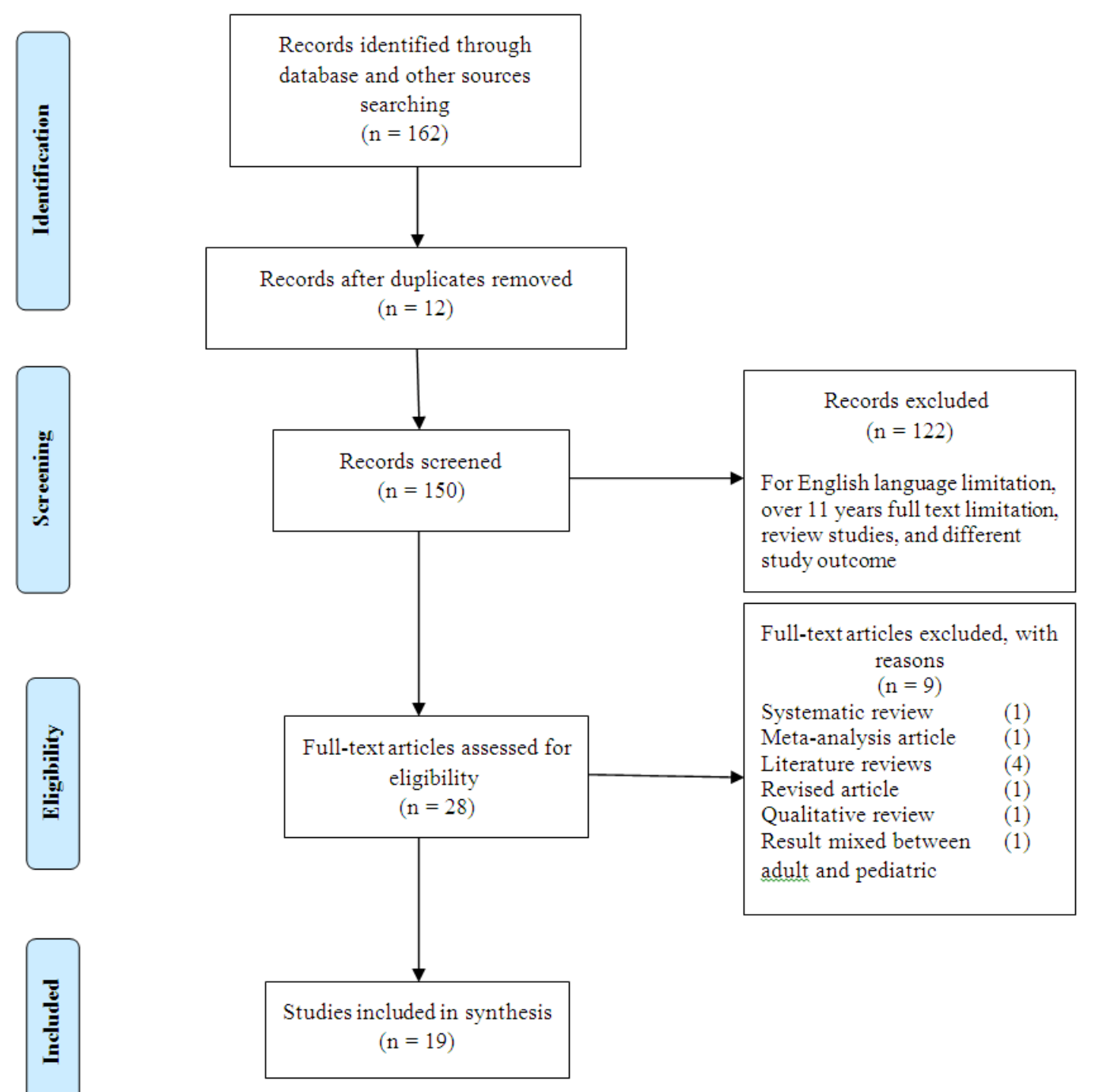

Figure 1. Flow Diagram: Selection Process for Literature Review ${ }^{[55]}$

\section{Results}

\subsection{Risk factors for PrU development}

Among the 19 articles that met the inclusion criteria, 11 studies identified risk factors that may accelerate the development of PrU in the critically ill patient population (see Table 1). Table 1 provides an overview of the year of publication, setting, population, study method, measures and results of each study. The studies presented in Table 1 will be discussed under relevant risk factors below. 
Table 1. Studies addressing factors associated with PrU in ICU

\begin{tabular}{|c|c|c|c|c|c|c|}
\hline $\begin{array}{l}\text { Author, year of } \\
\text { publication }\end{array}$ & Sample & Setting & $\begin{array}{l}\text { Study } \\
\text { method }\end{array}$ & $\begin{array}{l}\text { Potential predictor } \\
\text { variable }\end{array}$ & $\begin{array}{l}\text { Result } \\
\text { (Risk factors associated with PrU } \\
\text { development) }\end{array}$ & Limitations \\
\hline $\begin{array}{l}\text { Theaker et al } \\
(2000)^{[23]}\end{array}$ & 286 & $\begin{array}{l}\text { Medical \& } \\
\text { Surgical } \\
\text { ICU, } \\
\text { UK }\end{array}$ & Prospective & $\begin{array}{l}22 \text { Factors including } \\
\text { demographic and } \\
\text { clinical variables }\end{array}$ & $\begin{array}{l}\text { norepinephrine infusions, } \\
\text { APACHE II scores of } 13 \text { or above, } \\
\text { fecal incontinence, } \\
\text { anemia and } \\
\text { length of stay in ICU of }>3 \text { days }\end{array}$ & $\begin{array}{l}\text { Unmeasured factors such as } \\
\text { BMI could be significant. }\end{array}$ \\
\hline $\begin{array}{l}\text { Eachempati et } \\
\text { al (2001) }\end{array}$ & 3027 & $\begin{array}{l}\text { Surgical } \\
\text { ICU, } \\
\text { USA }\end{array}$ & Prospective & $\begin{array}{l}\text { Cornell ulcer risk score } \\
\text { APACH II } \\
\text { Systemic inflammatory } \\
\text { Multiple organ } \\
\text { dysfunction } \\
\text { Demographic data }\end{array}$ & $\begin{array}{l}\text { Emergency ICU admission } \\
\text { ICU LOS }>7 \text { days } \\
\text { Older age } \\
\text { Prolonged time without nutrition } \\
\text { Non-ambulatory status }\end{array}$ & Stage 1 PrU excluded \\
\hline $\begin{array}{l}\text { Fife et al } \\
(2001)^{[24]}\end{array}$ & 186 & $\begin{array}{l}\text { Neurologic } \\
\text { al ICU, } \\
\text { USA }\end{array}$ & $\begin{array}{l}\text { Prospective } \\
\text { cohort }\end{array}$ & $\begin{array}{l}\text { Demographic and } \\
\text { clinical data }\end{array}$ & $\begin{array}{l}\text { Braden scale } \leq 13 \\
\text { Low BMI on admission }\end{array}$ & Stage I PrU excluded. \\
\hline $\begin{array}{l}\text { Frankel et al } \\
(2007)^{[8]}\end{array}$ & 820 & $\begin{array}{l}\text { Surgical } \\
\text { ICU, } \\
\text { USA }\end{array}$ & $\begin{array}{l}\text { Retrospective } \\
\text { analysis }\end{array}$ & $\begin{array}{l}\text { Demographic and } \\
\text { laboratory data. } \\
\text { LOS } \\
\text { APACHE II }\end{array}$ & $\begin{array}{l}\text { history of diabetes, spinal cord injury, } \\
\text { renal insufficiency, and older age }>60 \\
\text { years }\end{array}$ & $\begin{array}{l}\text { The incidence of PrU was } \\
\text { low }(3 \%) \text {. } \\
\text { Excluded Stage I. } \\
\text { Difficulties acknowledged in } \\
\text { measurement of incidence } \\
\text { and prevalence rate. }\end{array}$ \\
\hline $\begin{array}{l}\text { Suriadi et al } \\
(2007)^{[53]}\end{array}$ & 105 & $\begin{array}{l}\text { ICUs, } \\
\text { Indonesia }\end{array}$ & $\begin{array}{l}\text { Prospective } \\
\text { cohort study }\end{array}$ & $\begin{array}{l}\text { Interface pressure } \\
\text { Skin moisture } \\
\text { Body temperature } \\
\text { Smoking. } \\
\text { Diastolic blood } \\
\text { pressure } \\
\text { Fecal incontinence } \\
\text { Nutritional status }\end{array}$ & $\begin{array}{l}\text { Increase interface pressure } \\
\text { Skin moisture } \\
\text { Increase body temperature } \\
\text { Smoking. }\end{array}$ & $\begin{array}{l}\text { Authors disregard the } \\
\text { underlying patient's } \\
\text { condition and treatment. } \\
\text { Many instruments to } \\
\text { measure interface pressure, } \\
\text { moisture and temperature. } \\
\text { Cigarette composition may } \\
\text { different from other } \\
\text { countries. }\end{array}$ \\
\hline $\begin{array}{l}\text { Nijis et al } \\
(2008)^{[26]}\end{array}$ & 520 & $\begin{array}{l}\text { Surgical } \\
\text { ICU, } \\
\text { Belgium }\end{array}$ & $\begin{array}{l}\text { Prospective } \\
\text { descriptive } \\
\text { research }\end{array}$ & $\begin{array}{l}\text { Demographic, clinical } \\
\text { data. Other preventive } \\
\text { measures such as } \\
\text { (frequent turning, } \\
\text { floating heels, } \\
\text { alternating mattresses } \\
\text { and sitting in chair) }\end{array}$ & $\begin{array}{l}\text { Vascular disease } \\
\text { Uses of Dopamine or Dobutamine } \\
\text { medication } \\
\text { Intermittent hemodialysis or continuous } \\
\text { veno-venous hemofiltration (renal } \\
\text { insufficiency) } \\
\text { Mechanical ventilation } \\
\text { Infrequent turning } \\
\text { Adequate prevention measures } \\
\text { Alternating mattresses } \\
\text { Floating heels } \\
\text { No association between the uses of } \\
\text { sedatives, patient's body temperature } \\
\text { above } 38.5 \mathrm{c} \text {, and sitting in chair and PrU } \\
\text { formation grade } 2-4 \text { in ICU. }\end{array}$ & Stage 1 PrU excluded. \\
\hline $\begin{array}{l}\text { Shahin et al } \\
(2009)^{[54]}\end{array}$ & 121 & $\begin{array}{l}\text { Nephrolog } \\
\mathrm{y}, \text { surgical } \\
\text { and } \\
\text { cardiology } \\
\text { ICUs, } \\
\text { Germany }\end{array}$ & $\begin{array}{l}\text { Longitudinal } \\
\text { study }\end{array}$ & $\begin{array}{l}\text { Assess demographic } \\
\text { and clinical data such as } \\
\text { (length of stay, } \\
\text { unconsciousness, } \\
\text { urinary catheter at } \\
\text { admission and existing } \\
\text { of pressure ulcer in } \\
\text { admission) with } \\
\text { Braden scale and } \\
\text { APACHE II }\end{array}$ & APACHE II score above 14. & Small sample size \\
\hline $\begin{array}{l}\text { Kaitani et al } \\
(2010)^{[5]}\end{array}$ & 606 & ICU, Japan & Prospective & $\begin{array}{l}\text { Severity of illness and } \\
\text { pressure ulcer } \\
\text { development }\end{array}$ & $\begin{array}{l}\text { Emergency ICU/HCU admission. } \\
\text { Infrequent turning. } \\
\text { APACHE II score not associated with } \\
\text { PrU development }\end{array}$ & $\begin{array}{l}\text { The lower APACH II score } \\
\text { is } 19.9\end{array}$ \\
\hline
\end{tabular}


Table 1. (Continued)

\begin{tabular}{|c|c|c|c|c|c|c|}
\hline $\begin{array}{l}\text { Author, year of } \\
\text { publication }\end{array}$ & Sample & Setting & $\begin{array}{l}\text { Study } \\
\text { method }\end{array}$ & $\begin{array}{l}\text { Potential predictor } \\
\text { variable }\end{array}$ & $\begin{array}{l}\text { Result } \\
\text { (Risk factors associated with PrU } \\
\text { development) }\end{array}$ & Limitations \\
\hline $\begin{array}{l}\text { Slowikowski \& } \\
\text { Funk (2010) }{ }^{[21]}\end{array}$ & 230 & $\begin{array}{l}\text { Surgical } \\
\text { ICU, } \\
\text { USA }\end{array}$ & Prospective & $\begin{array}{l}\text { Demographic and } \\
\text { clinical data }\end{array}$ & $\begin{array}{l}\text { History of diabetes. } \\
\text { Age }>70 \text { years } \\
\text { Low Braden scale }\end{array}$ & $\begin{array}{l}\text { Missing data for some } \\
\text { variables. } \\
\text { Data for some variables such } \\
\text { as (BMI and sedation) not } \\
\text { provided. }\end{array}$ \\
\hline
\end{tabular}

A total of 28 factors were identified as risk factors for PrU development in ICU patients. These are conceptualized and labeled as intrinsic (inherent factors of critical illness) and extrinsic (related to external forces) factors (see Table 2). The main risk factors identified or evidenced as enhancing PrU development in ICU setting by two or more studies will discussed below. Intrinsic factors identified in two or more studies were older age, increased length of stay in ICU and history of cardiovascular disease. Extrinsic factors identified in two or more studies were the administration of norepinephrine and patient repositioning (turning).

Older age usually involves skin alterations including a thinning of the epidermis, a $20 \%$ loss of dermal thickness, and the loss of elastin fibers ${ }^{[19]}$. Eachempati and colleagues examined age factors by multivariate analysis, and found that age was significantly associated with PrU development (OR 1.08, 95\% CI 0.0026-0.0131, $p=0.003)^{[20]}$. Frankel and team reported that older age was significantly associated with PrU development for surgical ICU (SICU) patients (OR 2.9, 95\% CI $1.2-7.1, p=0.022)^{[8]}$. Slowikowski and Funk using logistic regression analysis, also found that patients aged over 70 who were admitted to ICU had a significantly higher incidence of PrU development (OR 2.14, 95\% CI 1.27-3.62, $p=0.004)^{[21]}$. Recently, this result was confirmed by Cox who identified that age was a predictive factor for PrU development in ICU (OR $1.033,95 \%$ CI 1.003-1.064, $p=0.03)^{[22]}$. It appears clear that the older critically ill adult patient is vulnerable for PrU development.

Length of stay (LOS) in ICU is another commonly identified risk factor for PrU development. In three studies ${ }^{[20,22,23]}$, it was found that patients with an ICU LOS of greater than three days were at increased risk for PrU development. Eachempati and team, using univariate analysis, found that ICU patients with LOS of seven days or more were at high risk for PrU development $(p=0.0288)^{[20]}$. Theaker and associates showed that a longer stay in ICU for three days or more was significantly associated with PrU development (OR 2.76, 95\% CI 1.08-7.05, $p=0.034)^{[23]}$. Cox found a significant association between LOS and PrU development (OR 1.008, 95\% CI 1.004-1.012, $p<0.001)^{[22]}$. Significantly, Fife and colleagues argued, by correlation or logistic regression analysis, that LOS did not predict PrU development in a neurological ICU $(p=0.31)^{[24]}$. However, the authors conducted this study in a special population which included adults with spinal cord or closed head injuries who were more susceptible to PrU development because of prolonged immobility, also the authors did not acknowledge a reason for this association. Further research will be essential to clarify this association. While these papers clearly indicate a longer LOS increases the likelihood of an increased incidence of PrU development, it should also be considered that a longer LOS would logically correlate with an increased patient acuity.

Comorbidities including cardiovascular disease and diabetes can be one of the prognostic indicators for PrU development in ICU. Cardiovascular disease was found in several studies to be significantly associated with PrU development ${ }^{[22,25,26]}$. Boyle and Green reported that patients with cardiovascular instability were at higher risk of PrU occurrence $\left(\chi^{2}=6.850, p=\right.$ $0.009)^{[25]}$. Using logistic regression Cox found that a history of cardiovascular disease was a significant predictor of $\operatorname{Pr} U$ 
(OR 2.952, 95\% CI 1.3-6.4, $p=0.007)^{[22]}$. Similarly, Nijis and co-researchers, found a positive association between vascular disease and 24 hours before PrU occurrence (OR 4.51, 95\% CI 1.99-10.24, $p=0.001$ ) or 48 hours before PrU occurrence (OR 2.85, 95\% CI 1.29-6.30, $p=0.001)^{[26]}$. A possible explanation for this association is that cardiovascular disease predisposes patients to ischemia or reduced peripheral blood flow ${ }^{[26]}$. Patients with a compromised cardiac pump and vasculature disease are likely to exhibit lower capillary perfusion pressures which can be overcome with lower interface pressures. Thus, cardiovascular disease should be considered as a predictive factor for PrU development.

Table 2. Identified risk factors contributing to PrU development in ICU patients

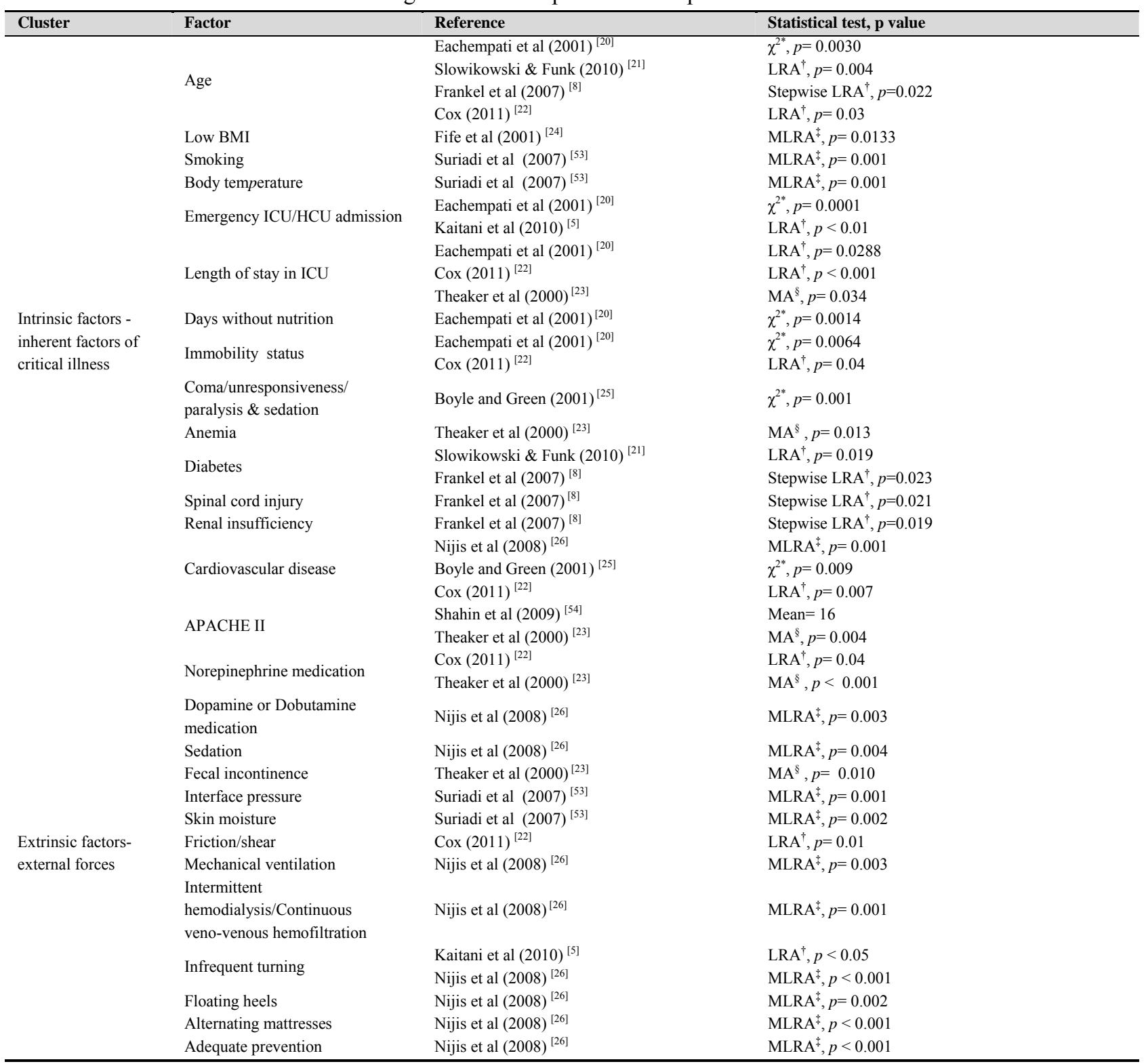

$*$ Chi-square; $\dagger$ Logistic regression analysis; $\$$ Multivariate Logistic regression analysis; $\S$ Multivariate analysis

Diabetes is a common disorder which effects vascular perfusion and may predispose patients to $\operatorname{PrU}$ development ${ }^{[8,21]}$. Frankel and team also reported that diabetes has positive association with PrU occurrence in SICU (OR 2.7, 95\% CI 1.1-6.4, $p=0.023)^{[8]}$. More recently, Slowikowski and Funk using logistic regression analysis found that diabetes significantly predicted PrU development in critically ill patients (OR 1.93, 95\% CI 1.11-3.35, $p=0.019$ ) ${ }^{[21]}$. Therefore, a history of diabetes has been found to be an indicator for developing pressure ulcers in ICU. 
Hemodynamic instability in critically ill patients leads to tissue hypoxia ${ }^{[6]}$. These patients also require vasoactive drugs, such as norepinephrine, to treat hypotension and maintain organ perfusion. Theaker and co-workers used a multivariate analysis to reveal that norepinephrine perfusion was positively associated with $\operatorname{PrU}$ occurrence (OR 8.11, 95\% CI 3.64-18.0, $p=0.001)^{[23]}$. Cox also found that norepinephrine perfusion was a significant predictor of stage II, or greater, PrU development (OR 1.017, 95\% CI 1.001-1.033, $p=0.04)^{[22]}$. It might also be considered that the use of norepinephrine while stabilizing hemodynamic function in optimal circumstances will also simultaneously reduce tissue perfusion. This too may potentially increase the risk of PrU.

While having many contributing factors, PrU occurrence is also dependent on the length of time an area is exposed to pressure. Patient's immobility is considered a preeminent factor for PrU development. In the ICU this could be a direct result of uses of sedation or patient's status - not simply patient acuity. Nijis and team showed a significant association between frequent of repositioning and time, with a period of 24 hours before PrU development (OR 6.66, 95\% CI $2.70-16.44, p=0.001$ ) being particularly relevant ${ }^{[26]}$. Recently, Kaitani and colleagues ${ }^{[5]}$ demonstrated that $\operatorname{PrU}$ development in an ICU could be predicted by analyzing the frequent of repositioning patient (OR $0.452,95 \% \mathrm{CI}$ 0.004-0.470, $p<0.01)$. Therefore, critically ill patients are at a greater risk of experiencing PrU due to their poor mobility.

\subsection{Pressure ulcer risk assessment scales}

Eleven articles were identified that examined PrU risk assessment scales in ICUs. Several risk assessment instruments have been developed for early screening of patients at higher risk of developing PrU in the ICU. Table 3 provides a summary of the year of publication, setting, population, study method, scale, cut-off point, sensitivity and results of each study. Table 4 provides background information and overviews of each risk assessment scale used in ICU including; items of assessment, score and total score, and determination of 'at risk' category.

The Braden scale, utilized in nine studies was the most commonly applied risk assessment scale in research studies included in this review. Recently, Gomes and team in across-sectional analytic study of 22 ICUs, found the moderate and high risk categories of the Braden scale to be highly predictive for PrU development (OR 5.54, 95\% CI 1.36-22.49, $p=$ 0.017 ), (OR 11.60, 95\% CI 3.56-37.74, $p=0.000$ ) respectively ${ }^{[27]}$. Lewicki and associates in a descriptive study in 337 cardiothoracic ICU patients examined the sensitivity and specificity of the Braden scale using different cut-off points at various days of hospitalization to determine the optimal cut-off point in a cardiac surgical population. The author recommended that several cut-off scores corresponding with day of hospitalization exist in populations whose conditions change greatly over the course of their hospital stay. Ongoing assessment is always required as the clinical status of patients is liable to change ${ }^{[28]}$.

Other scales used in the ICU setting include the Jackson/Cubbin ${ }^{[29-31]}$, Waterlow ${ }^{[25,32,33]}$, Modified Norton ${ }^{[34]}$, Suriadi and Sanda ${ }^{[35]}$, and Douglas ${ }^{[30]}$. De Araujo and collaborates found the Waterlow scale to be significantly predictive for patients at risk for PrU development $(p=0.005)$ in comparison with the Braden or Norton scales ${ }^{[32]}$. Boyle and Green meanwhile argue that the Waterlow scale and Jackson/Cubbin scale are not predictive for patients at risk for PrU development in ICU ( $p=0.92, p=0.47$ respectively ${ }^{[25]}$. Using Chi square analysis Boyle and Green, found that the "high risk" category only in Jackson/Cubbin scale was positively associated with $\operatorname{PrU}$ development $(p=0.0005)^{[25]}$.

The Jackson/Cubbin scale was a modification of the Norton scale which was developed and revised specifically for ICU patients. Seongsook and coworkers tested the sensitivity and specificity of three risk assessment scales in ICU, the Braden, Jackson/Cubbin, and Douglas scale, and found that Jackson/Cubbin scale was more valid as its sensitivity was $89 \%$ and specificity $61 \%$ in comparison with the two other scales ${ }^{[30]}$. Also Kim and co-researchers prospectively examined different risk assessment scales, namely Braden, Song and Choi, and Jackson/Cubbin scale and found that Jackson/Cubbin was higher predictor for PrU than the two scales, with a sensitivity of $95 \%$ and specificity of $81.5 \%{ }^{[31]}$. However the reliability of these scales were not reported. 
Table 3. Studies examined the effectiveness of risk assessment scale for PrU development

\begin{tabular}{|c|c|c|c|c|c|c|c|c|}
\hline $\begin{array}{l}\text { Author, year of } \\
\text { publication }\end{array}$ & Sample & Setting & $\begin{array}{l}\text { Study } \\
\text { method }\end{array}$ & $\begin{array}{l}\text { Scale/ } \\
\text { Assessment }\end{array}$ & $\begin{array}{l}\text { Cut-off } \\
\text { point* }\end{array}$ & Sensitivity (\%) & Specificity (\%) & Result \\
\hline $\begin{array}{l}\text { Lewicki et al } \\
(2000)^{[28]}\end{array}$ & 337 & $\begin{array}{l}\text { Cardiac } \\
\text { surgical } \\
\text { ICU }\end{array}$ & $\begin{array}{l}\text { Prospective } \\
\text { cohort }\end{array}$ & Braden scale & $\begin{array}{l}\text { Cutoff } \\
\text { Braden scale } \\
\text { score varied } \\
\text { by hospital } \\
\text { day }\end{array}$ & $\begin{array}{l}1^{\text {st }} \text { day }(13)=50 \% \\
3^{\text {rd }} \text { days }(14)=57.1 \\
5^{\text {th }} \text { days }(20)=50\end{array}$ & $\begin{array}{l}1^{\text {st }} \text { day }(13)=45.7 \\
3^{\text {rd }} \text { days }(14)=92 \\
5^{\text {th }} \text { days }(20)=70.9\end{array}$ & $\begin{array}{l}\text { On } 1^{\text {st }} \text { day } \\
\text { postoperative, } 67 \% \text { of } \\
\text { patients were identified } \\
\text { as PrU positive with } \\
\text { cut-off } 13 \\
\text { On } 3^{\text {rd }} \text { day, } 57 \% \text { with } \\
\text { cut-off } 14 \\
\text { On } 5^{\text {th }} \text { day, } 50 \% \text { with } \\
\text { cut-off } 20\end{array}$ \\
\hline $\begin{array}{l}\text { Boyle and } \\
\text { Green }(2001)^{[25]}\end{array}$ & $\begin{array}{l}314 \\
188\end{array}$ & ICU & $\begin{array}{l}\text { Prospective } \\
\text { observational }\end{array}$ & $\begin{array}{l}\text { Waterlow } \\
\text { scale } \\
\text { Jackson/cubb } \\
\text { in scale }\end{array}$ & $\begin{array}{l}\geq 10 \\
\leq 29\end{array}$ & Not reported & Not reported & $\begin{array}{l}\text { Waterlow scale (all } \\
\text { categories) is not } \\
\text { significantly predictive } \\
\text { for PrU occurrence. } \\
\text { High risk category of } \\
\text { Jackson/ Cubbin scale } \\
\text { is significantly } \\
\text { predictive for PrU } \\
\text { development }\end{array}$ \\
\hline $\begin{array}{l}\text { Fife et al } \\
(2001)[24]\end{array}$ & 186 & $\begin{array}{l}\text { ICU } \\
\text { (Neurol } \\
\text { ogical) }\end{array}$ & $\begin{array}{l}\text { Prospective } \\
\text { cohort }\end{array}$ & Braden scale & $\leq 13$ & 91.4 & Not reported & $\begin{array}{l}\text { Braden scale } \leq 13 \text { score } \\
\text { predicting to } \operatorname{Pr} U \\
\text { development. }\end{array}$ \\
\hline $\begin{array}{l}\text { Seongsook et al } \\
(2004)^{[30]}\end{array}$ & 112 & ICU & $\begin{array}{l}\text { Longitudinal } \\
\text { study }\end{array}$ & $\begin{array}{l}\text { Braden } \\
\text { Jackson/Cub } \\
\text { bin } \\
\text { Douglas }\end{array}$ & $\begin{array}{l}\leq 16 \\
\leq 24 \\
\leq 18\end{array}$ & $\begin{array}{l}79 \\
89 \\
100\end{array}$ & $\begin{array}{l}26 \\
61 \\
18\end{array}$ & $\begin{array}{l}\text { Jackson/Cubbin scale } \\
\text { has higher validity }\end{array}$ \\
\hline $\begin{array}{l}\text { Feuchtinger et } \\
\text { al }(2007)^{[34]}\end{array}$ & 53 & $\begin{array}{l}\text { ICU } \\
\text { (cardiac } \\
\text { surgery) }\end{array}$ & $\begin{array}{l}\text { Explorative } \\
\text { prospective } \\
\text { study }\end{array}$ & $\begin{array}{l}\text { Braden } \\
\text { Modified } \\
\text { Norton } \\
\text { 4-factor } \\
\text { model }\end{array}$ & $\begin{array}{l}\leq 20 \\
\leq 25 \\
\geq 2\end{array}$ & $\begin{array}{l}97 \\
58 \\
85\end{array}$ & $\begin{array}{l}5 \\
47 \\
31\end{array}$ & $\begin{array}{l}\text { Braden scale has higher } \\
\text { validity for cardiac } \\
\text { surgery ICU }\end{array}$ \\
\hline $\begin{array}{l}\text { Suriadi et al } \\
(2007)^{[35]}\end{array}$ & 253 & $\begin{array}{l}\text { ICU in } \\
\text { Indonesi } \\
\text { a }\end{array}$ & $\begin{array}{l}\text { Prospective } \\
\text { cohort }\end{array}$ & $\begin{array}{l}\text { Suriadi and } \\
\text { Sanada scale }\end{array}$ & S.S $>4$ & 81 & 83 & $\begin{array}{l}\text { PrU incidence in first } \\
\text { ICU: } 27 \% \\
\text { Second ICU: } 31 \%\end{array}$ \\
\hline $\begin{array}{l}\text { Kottner \& } \\
\text { Dassen } \\
(2009)^{[33]}\end{array}$ & 45 & $\mathrm{ICU}$ & $\begin{array}{l}\text { Observationa } \\
1\end{array}$ & $\begin{array}{l}\text { Braden scale } \\
\text { Waterlow } \\
\text { scale } \\
\text { Subjective } \\
\text { scale }\end{array}$ & Not reported & Not reported & Not reported & $\begin{array}{l}\text { The three scales are not } \\
\text { recommended in ICU } \\
\text { Braden scale was more } \\
\text { reliable in comparison. }\end{array}$ \\
\hline $\operatorname{Kim}(2009)^{[31]}$ & 219 & $\begin{array}{l}\text { ICU } \\
\text { (Surgica } \\
\text { 1) } \\
\text { In Korea }\end{array}$ & $\begin{array}{l}\text { Non-experim } \\
\text { ental } \\
\text { prospective } \\
\text { study }\end{array}$ & $\begin{array}{l}\text { Braden scale } \\
\text { Song and } \\
\text { Choi scale } \\
\text { Jackson/cubb } \\
\text { in }\end{array}$ & $\begin{array}{l}\text { Braden } \leq 24 \\
\text { Song and } \\
\text { Choi } \leq 21 \\
\text { Jackson/Cub } \\
\text { bin } \leq 28\end{array}$ & $\begin{array}{l}\text { Braden }(92.5) \\
\text { Song and Choi } \\
(95) \\
\text { Jackson/Cubbin } \\
(95)\end{array}$ & $\begin{array}{l}\text { Braden } 69.8 \\
\text { Song and Choi } \\
69.2 \\
\text { Jackson/Cubbin } \\
81.5\end{array}$ & $\begin{array}{l}\text { Jackson/Cubbin was the } \\
\text { most effective scale in } \\
\text { prediction PrU }\end{array}$ \\
\hline $\begin{array}{l}\text { Slowikowski \& } \\
\text { Funk }(2010)^{[21]}\end{array}$ & 230 & $\begin{array}{l}\text { Surgical } \\
\text { ICU } \\
\text { in USA }\end{array}$ & Prospective & Braden scale & Not reported & Not reported & Not reported & $\begin{array}{l}\text { Braden scale was } \\
\text { effective scale in } \\
\text { prediction } \operatorname{PrU} \text { patients }\end{array}$ \\
\hline $\begin{array}{l}\text { de Araujo et al } \\
(2011)^{[32]}\end{array}$ & 42 & $\begin{array}{l}\text { ICU } \\
\text { In Brazil }\end{array}$ & $\begin{array}{l}\text { Exploratory } \\
\text { and } \\
\text { Longitudinal } \\
\text { study }\end{array}$ & $\begin{array}{l}\text { Norton scale } \\
\text { Braden scale } \\
\text { Waterlow } \\
\text { scale }\end{array}$ & $\begin{array}{l}\text { Norton } \leq 14 \\
\text { Braden } \leq 16 \\
\text { Waterlow } \geq \\
10\end{array}$ & Not reported & Not reported & $\begin{array}{l}\text { The Waterlow scale has } \\
\text { higher score in PrU risk } \\
\text { assessment in } \\
\text { comparison to Norton } \\
\text { and Braden scales }\end{array}$ \\
\hline $\begin{array}{l}\text { Gomes et al } \\
(2011)^{[27]}\end{array}$ & 140 & $\mathrm{ICU}$ & $\begin{array}{l}\text { A } \\
\text { crosssectiona } \\
1 \text { and analytic } \\
\text { study }\end{array}$ & Braden scale & Not reported & Not reported & Not reported & $\begin{array}{l}\text { Braden scale was high } \\
\text { predictive for } \operatorname{Pr} U\end{array}$ \\
\hline
\end{tabular}

${ }^{*}$ Cut-off point divides the sample into two groups. One group has significantly risk for developing pressure ulcer, while the other group no significantly risk

The Suriadi and Sanda scale was developed for ICU patients in Indonesia. This scale produced a balance between sensitivity $(81 \%)$ and specificity $(83 \%)^{[35]}$. However, the author noted several limitation with this scale including; specific factors that may be unique on Indonesian populations and the influence of cigarette composition of nicotine and tar which may differ from other countries. To confirm this result, a longitudinal study in different populations is essential. 
Table 4. Comparison of the concepts of the risk assessment instruments

\begin{tabular}{|c|c|c|c|c|}
\hline Scale & Item & Score & Total (min,max) & At risk \\
\hline Norton & $\begin{array}{l}\text { Physical condition } \\
\text { Level of consciousness } \\
\text { Activity } \\
\text { Mobility } \\
\text { Incontinence }\end{array}$ & $\begin{array}{l}\text { Each subscale } \\
\text { rated from } 1 \text { to } 4\end{array}$ & 5 to 20 & $\begin{array}{l}\text { Lower score, higher risk of pressure ulcer formation } \\
\text { the score } \leq 14 \text { for patients at risk. }\end{array}$ \\
\hline Modified Norton & $\begin{array}{l}\text { Skin condition } \\
\text { Cooperation/motivation } \\
\text { Physical condition } \\
\text { Additional diseases } \\
\text { Mental state } \\
\text { Incontinence } \\
\text { Activity } \\
\text { Mobility } \\
\text { Age }\end{array}$ & $\begin{array}{l}\text { Each subscale } \\
\text { rated from } 1 \text { to } 4\end{array}$ & $\leq 25$ & Lower score, higher risk of pressure ulcer formation \\
\hline 4- factor model & $\begin{array}{l}\text { Sensory perception } \\
\text { Moisture } \\
\text { Friction and shear } \\
\text { Age }\end{array}$ & 1 & $>2$ & Higher score, higher risk of pressure ulcer formation \\
\hline Braden & $\begin{array}{l}\text { sensory perception, activity and } \\
\text { mobility; moisture, } \\
\text { nutritional status } \\
\text { friction/shear }\end{array}$ & $\begin{array}{l}\text { Each subscale } \\
\text { rated from } 1 \text { to } 3 \text { or } \\
4\end{array}$ & 6 to 23 & $\begin{array}{l}\text { The score for mild-risk patients is } 15-16 \text {, for } \\
\text { moderate risk is } 12-14 \text { and for high risk is } 11 \text { or } \\
\text { below. } \\
\text { Thus, lower score, a higher risk of PrU development }\end{array}$ \\
\hline Waterlow & $\begin{array}{l}\text { build/weight, continence, skin type, } \\
\text { mobility, gender, age, appetite, tissue } \\
\text { malnutrition, neurological deficit, } \\
\text { surgery/trauma and specific } \\
\text { medications }\end{array}$ & $\begin{array}{l}\text { Each subscale rate } \\
\text { from } 0 \text { to } 3 \text { or } 5 \text { or } \\
8\end{array}$ & $<10$ to $>20$ & $\begin{array}{l}\text { Scores between } 10 \text { and } 14 \text { is n the 'at-risk group', } \\
\text { between } 15 \text { and } 19 \text { in the 'high-risk group', and } 20 \\
\text { or above in the 'very high-risk group' } \\
\text { Higher score, higher risk of pressure ulcer formation }\end{array}$ \\
\hline Suriadi and Sanada (S.S) & $\begin{array}{l}\text { Interface pressure } \\
\text { Body temperature } \\
\text { Cigarette smoking }\end{array}$ & $\begin{array}{l}\text { Interface pressure, } \\
\text { in } \mathrm{mmHg},(3 \text { and } \\
0) \\
\text { Body temperature } \\
(4 \text { and } 0) \\
\text { Cigarette smoking } \\
(2 \text { and } 0)\end{array}$ & $0-9$ & Higher score, higher risk of pressure ulcer formation \\
\hline $\begin{array}{l}\text { Douglas scale } \\
\text { (adapter of Norton) }\end{array}$ & $\begin{array}{l}\text { Pain } \\
\text { Activity } \\
\text { Physical condition } \\
\text { Incontinence } \\
\text { Steroid therapy } \\
\text { Diabetes } \\
\text { Cytotoxic therapy } \\
\text { Dyspnea }\end{array}$ & & 8 to 24 & Lower score, a higher risk of PrU development \\
\hline $\begin{array}{l}\text { Jackson/Cubbin } \\
\text { (adaption of the Norton } \\
\text { scale) }\end{array}$ & $\begin{array}{l}\text { Age } \\
\text { Weight } \\
\text { General skin } \\
\text { Mental condition } \\
\text { Mobility } \\
\text { Hemodynamic status } \\
\text { Respiration } \\
\text { Nutrition } \\
\text { Incontinence } \\
\text { Hygiene }\end{array}$ & $\begin{array}{l}\text { Each scale is rated } \\
\text { from } 1-4\end{array}$ & 10 to 40 & Lower score, a higher risk of $\operatorname{Pr} U$ development \\
\hline $\begin{array}{l}\text { Song and Choi } \\
\text { (adapter of Braden) }\end{array}$ & $\begin{array}{l}\text { Body temperature } \\
\text { Amount of medication (analgesics, } \\
\text { sedation and anticoagulants) } \\
\text { Sensory perception, activity and } \\
\text { mobility } \\
\text { moisture, } \\
\text { nutritional status, friction/shear }\end{array}$ & $\begin{array}{l}\text { Each subscale is } \\
\text { rated from } 1-3 \text { or } 4\end{array}$ & 8 to 31 & Lower score, a higher risk of $\operatorname{Pr} U$ development \\
\hline
\end{tabular}

Considering the review of these PrU risk assessment tools there appears a lack of consistency regarding the appropriate risk assessment scale in ICU settings. It would appear further research to clarify a valid and reliable PrU risk assessment tool for the ICU setting is needed. 


\section{Discussion}

\subsection{Risk factors for PrU development}

The first aim of this review was to identify factors or risks that contribute to PrU development in ICU. Schoonhovan argues that the cornerstone of PrU prevention is to identify, assess and manage potential risk before an injury occurs ${ }^{[36]}$. Identification of potential risk is important however, results from this review suggest that PrU formation is enhanced by presence of multiple, rather than single, risk factors in the one critically ill individual ${ }^{[23]}$. Sound evidence demonstrates that older age ${ }^{[8,20-22]}$, length of stay ${ }^{[20,22,23]}$, norepinephrine infusion ${ }^{[22,23]}$ and prolonged immobility ${ }^{[5,26]}$ were significantly associated with PrU development in ICU patients. These risk factors will each be discussed.

\subsubsection{Age}

Patient age was evidenced by literature to be a predictive variable for PrU development in ICU patients. While critical illness has a significant impact on the older adult, older people are at high risk for skin breakdown also because of limitations in their mobility. Additionally, their skin becomes fragile and thin and they have a predisposition to degenerative and other diseases ${ }^{[37]}$. These considerations suggest the effects of ageing on skin integrity cannot be preventable, but rather need to be managed more carefully. Aggressive implementation of preventative measures in this patient group such as use of appropriate pressure relieving mattresses and other support surfaces, frequent turning, regular bathing and the prevention of skin tears will greatly reduce the risk of PrU.

\subsubsection{Length of stay}

As evidenced by numerous studies in this review ${ }^{[20,22,23]}$, the longer the patient remains in ICU, the greater the risk of PrU development. This would be viewed as a logical conclusion as higher acuity patients may have a longer length of stay and are consequently at a greater potential for risk of complications, such as $\operatorname{PrU}$ development.

\subsubsection{Norepinephrine}

The nature of critical illness often results in the majority of ICU patients presenting with impaired ventilation and circulation, which affects body tissue oxygenation. This issue may be ameliorated by special medications such as norepinephrine. Norepinephrine acts via the binding to adrenergic receptors, which causes peripheral vasoconstriction, and may further impair peripheral tissue perfusion leading to peripheral cellular hypoxia ${ }^{[38]}$, which causes ischemia. Thus profound peripheral vasoconstriction with norepinephrine administration leads to reduced local circulation and increased risk of PrU development. Bedside nurses need to be cognizant of the patients medication regime and its potential effects when implementing PrU reduction measures i.e. such patients may require higher level pressure relieving mattresses and more frequent turning.

\subsubsection{Prolonged immobility}

Infrequent turning for ICU patients has a significant impact on PrU development. Infrequent turning will result in increased pressure on one point for prolonged periods of time. However, there is no evidence for the optimum frequency for repositioning the critically ill ICU patients. Two-hourly repositioning of patients is accepted as standard practice on the basis of anecdotal data ${ }^{[39]}$. Goldhill and colleagues undertook a prospective observational study to examine ICU patient position and frequency of turning. They identified the mean time between turning for patients in over 50 ICUs in the United Kingdom was 4.88 hours ${ }^{[40]}$. Tayyib and her group found the mean time between patient repositioning in a Saudi Arabian ICU to be two hours ${ }^{[41]}$. The reviewed studies described the mean time to reposition an ICU patient were between two ${ }^{[5]}$ and four hours ${ }^{[26]}$. Therefore, while the mean time for repositioning critically ill patients will vary across countries and even individual ICUs within a country, it should still be recognized that, for the most part, turning regimes in ICU aim to reposition patients within time frames of two to four hours. As such repositioning practices should be sensitive to individual patient needs. 


\subsubsection{Summary}

It should be noted that a risk factor prediction model for critically ill patients has yet to be developed. Development of a model is, however, problematic as there are a multiple risk factors to be considered. Further contributing to this the studies reviewed have utilized different methodologies, different measures of analyses, varying PrU definitions and $\operatorname{PrU}$ classifications, and examined PrU across a diverse ICU population. Consequently development of a risk factor prediction model would be difficult. Further, these complexities have limited the translation and implementation of this research into clinical practice ${ }^{[6]}$. Ideally, to examine the association between risk factors and PrU development a multicentre longitudinal prospective observational study is needed.

\subsection{Pressure ulcer risk assessment scales}

The second aim of this review was to examine published studies exploring risk assessment scales that predict PrU development in critically ill patients in ICU settings. In this section, discussion of the reviewed studies will focus on reported reliability, validity measures and sensitivity and specificity of the instruments ${ }^{[42]}$.

\subsubsection{Reliability}

Reliability concerns a measure's accuracy and for the purpose of this review relates to the frequency with which the risk assessment tool produces similar results in the absence of change in the patient's status (inter- rater reliability) and stability of the instrument over period of time (test-retest reliability). Only three studies included this review assessed inter-rater reliability of the following scales; Braden scale ${ }^{[28]}$, Braden and Waterlow scale ${ }^{[33]}$, and Suriadi and Sanada scale ${ }^{[35]}$. The Braden scale demonstrated high reliablility (Pearson's r: $0.83-0.99)^{[28]}$. Kottner \& Dassen (2009) confirmed that the Braden scale has high inter-rater reliability value compared to Waterlow scale ${ }^{[33]}$. However, Pancorbo-Hidalgo et al. (2006) demonstrated that the Braden scale is reliable in terms of inter- rater reliability compared to other risk assessment scales for prediction patient who at risk for PrU development such as Norton, Waterlow and Cubbin/ Jacksoon scale ${ }^{[42]}$. The Suriadi and Sanada scale showed high inter-rater reliability $(r=1)$, but this scale was examined in a single study for a specific population ${ }^{[35]}$. No studies included in this review reported test-retest reliability. Further, reliability of the scales may influenced by many factors such as training on the use of the risk assessment scale, and competence of individual nurses who assessing patients at risk ${ }^{[33]}$.

\subsubsection{Validity}

Validity refers to the accuracy of the scale. In terms of predictive validity three types of validity exist; content, construct and criterion validity ${ }^{[43]}$. Predictive validity refers to the ability of an instrument to consistently identify those patients who are at risk for developing PrU ${ }^{[6]}$. The National Pressure Ulcer Advisory Panel examined predictive validity of numerous risk assessment scales, for example; Braden scale ${ }^{[43]}$. The majority of the studies included in this review examined predictive validity through sensitivity and specificity, and the receiver operating curve (ROC) ${ }^{[28,30,31,33,35]}$.

\section{Sensitivity, specificity and ROC}

Sensitivity is defined as the proportion of true positives for patients at risk of PrU development who are correctly identified by the scale as at risk. Specificity is defined as the proportion of patients who did not develop PrUs and were correctly identified by the scale as not at risk ${ }^{[4,45]}$. Further to this, the appropriate cut-off point for determination of 'at risk' status for the PrU risk scale is an important consideration. Investigators often use appropriate statistical analysis to detect cut-off points such as receiver operating curve (ROC) ${ }^{[44]}$. The ROC also measures the association between predictive validity and the scale ${ }^{[4]}$.

This review has highlighted that existing risk assessment scales may potentially over-predict patients at risk for PrU development (as the sensitivity of the existing scales was reported as acceptable but the specificity reported was low i.e.

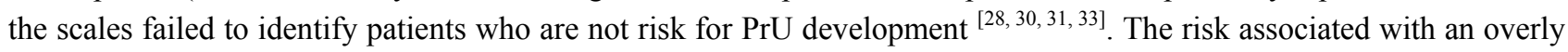
sensitive risk assessment scale is that patients may receive prevention measures that they do not need resulting in increased 
costs for the health care facility. Although, the Suriadi and Sanda scale achieved a sound sensitivity and specificity for an Indonesian population ${ }^{[35]}$, a quasi-experimental trial is needed to clarify this result in different countries.

The review ${ }^{[28,30,31,33,35]}$ also highlighted fluctuations of reported specificity and sensitivity values between different studies. These varying results may arise from differences among study settings, populations, PrU definition, outcome measures, patient's demographic data, sample sizes and preventive measures which have been implemented. Additionally, performance of risk assessment scales depends on the competence of individual nurses who assess risk in different ways ${ }^{[46]}$.

However, Defloor and Grypdonck suggest that the comparison between risk assessment scales using specificity and sensitivity is meaningless, and the differences between the scales is doubtful ${ }^{[47]}$. Defloor and Grypdonck argue that scale items do not consider preventative measures which can impact the PrU outcome and thus their value cannot be generalized ${ }^{[48]}$. This poses the question as to whether or not the validity of the scales can be measured through sensitivity, specificity and predictive values ${ }^{[49]}$. Since the ideal scale has yet to be developed, these measures should be calculated to test risk assessment scales.

Further, debate continues regarding the use of risk assessment scales for critically ill patients in the ICU. Seongsook stated that the identification of patients who are at risk for PrU would increase nursing care efficiency and be more cost effective ${ }^{[30]}$, while Pender and Frazier state that almost all ICU patients are almost at risk for PrU development ${ }^{[50]}$. Similarly, Webster and team stated that patients who are unable to reposition themselves independently should be automatically considered as at high risk for PrU development ${ }^{[51]}$. It is timely to consider this argument for ICU patients who are largely immobile, and by the nature of their critical illness, at high risk for PrU development. The current international NPUAP/EPUAP guidelines recommend that risk assessment scales should be used in conjunction with the implementation of preventative PrU measures and a clear evaluative framework which examines all factors influencing the PrU risk scale ${ }^{[52]}$.

\section{Limitations}

This review is limited by a number of factors. Firstly, the review was based on specific exclusion and inclusion criteria. Consequently this yielded a smaller number of studies. However, as the last previous work in this field was published in $2002^{[6]}$, the intent of this study was to review studies published after this date contributing to the body of knowledge in this area. Secondly, the inclusion of studies only published in the English language may have introduced a risk of language bias. However, it was beyond the financial scope of this review to include studies requiring translation into English. Consequently, it is acknowledged that this review does not include a potential body of work in this field. Finally, the 19 studies reviewed demonstrated inconsistency in methodological approaches and quality making in-depth synthesis and generalization of results across ICU population difficult.

\section{Conclusion}

This review identified 28 intrinsic (inherent factors of critical illness related) and extrinsic (external forces related) risk factors for PrU development in the adult ICU patient population. While ICU patients are confronted with multiple factors for potential PrU development, there is inconsistency specific to how these factors are measured. Furthermore, several risk assessment scales have been examined in many studies in terms of predictive performance. There is no consistent or clear evidence which demonstrates any scale to better or more effective than another when used to identify the patients at risk for PrU development. Many scales were found to have problems with validity or to be over predictive. There is therefore, a strong need to undertake well designed prospective studies to identify the risk factors and develop valid scales for measuring the risk of PrU development in ICU. 


\section{References}

[1] Niezgoda, J.A. and S. Mendez-Eastman. The effective management of pressure ulcers. Advances in Skin \& Wound Care. 2006 ; 19 Suppl 1(Supplement 1): 3-15.

[2] Guyton, A.C. and J.E. Hall. Textbook of medical physiology. 2006: Elsevier Saunders.

[3] Bouten, C.V., et al., The etiology of pressure ulcers: skin deep or muscle bound? The Archives of Physical Medicine and Rehabilitation. 2003; 84(4): 616-619. PMid:12690603 http://dx.doi.org/10.1053/apmr.2003.50038

[4] Youngman, A. Pressure ulcer prevention and pressure-relieving surfaces. British Journal of Nursing. 2008; 17(13): 830-835.

[5] Kaitani, T., et al. Risk factors related to the development of pressure ulcers in the critical care setting. Journal of clinical nursing. 2010; 19(3-4): 414-421. PMid:20500281 http://dx.doi.org/10.1111/j.1365-2702.2009.03047.x

[6] Keller, B.P.J.A., et al. Pressure ulcers in intensive care patients: a review of risks and prevention. Intensive care medicine. 2002; 28(10): 1379-1388. PMid:12373461 http://dx.doi.org/10.1007/s00134-002-1487-z

[7] Shahin, E.S.M., T. Dassen, and R.J.G. Halfens. Pressure ulcer prevalence and incidence in intensive care patients: a literature review. Nursing in Critical Care. 2008; 13(2): 71-79. PMid:18289185 http://dx.doi.org/10.1111/j.1478-5153.2007.00249.x

[8] Frankel, H., J. Sperry, and L. Kaplan. Risk Factors for Pressure Ulcer Development in a Best Practice Surgical Intensive Care Unit. American Surgeon. 2007; 73(12): 1215-1217. PMid:18186374

[9] Ballard, N., et al. How our ICU decreased the rate of hospital-acquired pressure ulcers. Journal of nursing care quality. 2008; 23(1): 92-96. PMid:18281882 http://dx.doi.org/10.1097/01.NCQ.0000303811.39737.b4

[10] Elliott, R., S. McKinley, and V. Fox. Quality improvement program to reduce the prevalence of pressure ulcers in an intensive care unit. American journal of critical care: an official publication, American Association of Critical-Care Nurses. 2008; 17(4): 328.

[11] Tubaishat, A., D. Anthony, and M. Saleh. Pressure ulcers in Jordan: A point prevalence study. Journal of Tissue Viability. 2011; 20(1): 14-19. PMid:20880710 http://dx.doi.org/10.1016/j.jtv.2010.08.001

[12] Baharestani, M.M., et al. Dilemmas in measuring and using pressure ulcer prevalence and incidence: an international consensus. International wound journal. 2009; 6(2): 97-104. PMid:19432659 http://dx.doi.org/10.1111/j.1742-481X.2009.00593.x

[13] Johnson, K.L. and T. Meyenburg. Physiological rationale and current evidence for therapeutic positioning of critically ill patients. AACN advanced critical care. 2009; 20(3): 228-240. PMid:19638744 http://dx.doi.org/10.1097/NCI.0b013e3181add8db

[14] Vollman, K.M. Introduction to progressive mobility. Critical Care Nurse. 2010; 30(2): S3-5. PMid:20360443 http://dx.doi.org/10.4037/ccn2010803

[15] Bennett, G., C. Dealey, and J. Posnett, The cost of pressure ulcers in the UK. Age and ageing. 2004; 33(3): $230-235$. PMid:15082426 http://dx.doi.org/10.1093/ageing/afh086

[16] Whittington, K., M. Patrick, and J.L. Roberts. A national study of pressure ulcer prevalence and incidence in acute care hospitals. Journal of Wound Ostomy \& Continence Nursing. 2000; 27(4): 209-215. PMid:10896746

[17] Graves, N., F. Birrell, and M. Whitby. Effect of pressure ulcers on length of hospital stay. Infection control and hospital epidemiology: the official journal of the Society of Hospital Epidemiologists of America. 2005; 26(3): 293-297. PMid:15796283 http://dx.doi.org/10.1086/502542

[18] National Pressure Ulcer Advisory Panel and European Pressure Ulcer Advisory Panel. International Guideline-Pressure Ulcer Treatment Technical Report. 2009 [cited 2012 November 27]. Available from: http://www.npuap.org/wp-content/uploads/2012/03/Final-2009-Treatment-Technical-Report1.pdf.

[19] Baranoski, S. Skin tears: Guard against this enemy of frail skin. Nursing Management. 2001; 32(8): 25. PMid:15129526 http://dx.doi.org/10.1097/00006247-200108000-00010

[20] Eachempati, S.R., L.J. Hydo, and P.S. Barie, Factors influencing the development of decubitus ulcers in critically ill surgical patients. Critical care medicine. 2001; 29(9): 1678-1682. PMid:11546964 http://dx.doi.org/10.1097/00003246-200109000-00004

[21] Slowikowski, G.C. and M. Funk. Factors associated with pressure ulcers in patients in a surgical intensive care unit. Journal of wound, ostomy, and continence nursing: official publication of The Wound, Ostomy and Continence Nurses Society / WOCN. 2010; 37(6): 619-626. PMid:21076261 http://dx.doi.org/10.1097/WON.0b013e3181f90a34

[22] Cox, J. Predictors of pressure ulcer development in adult critical care patients. 2010.

[23] Theaker, C., et al. Risk factors for pressure sores in the critically ill. Anaesthesia. 2000; 55(3): 221-221. PMid:10671839 http://dx.doi.org/10.1046/j.1365-2044.2000.01216.x

[24] Fife, C., et al. Incidence of pressure ulcers in a neurologic intensive care unit. Critical care medicine. 2001; 29(2): 283-290. PMid:11246307 http://dx.doi.org/10.1097/00003246-200102000-00011

[25] Boyle, M. and M. Green. Pressure sores in intensive care: defining their incidence and associated factors and assessing the utility of two pressure sore risk assessment tools. Australian Critical Care. 2001; 14(1): 24-30. http://dx.doi.org/10.1016/S1036-7314(01)80019-9 
[26] Nijs, N., et al., Incidence and risk factors for pressure ulcers in the intensive care unit. Journal of clinical nursing. 2009; 18(9): 1258-1266. PMid:19077028 http://dx.doi.org/10.1111/j.1365-2702.2008.02554.x

[27] Gomes, F.S.L., et al. Risk assessment for pressure ulcer in critical patients. Revista da Escola de Enfermagem da USP. 2011; 45(2): 313-318. http://dx.doi.org/10.1590/S0080-62342011000200002

[28] Lewicki, L.J., L.C. Mion, and M. Secic. Sensitivity and specificity of the Braden Scale in the cardiac surgical population. Journal of Wound Ostomy \& Continence Nursing. 2000; 27(1): 36-41. PMid:10649141

[29] Hunt, J. Application of a pressure area risk calculator in an intensive care unit. Intensive and Critical Care Nursing. 1993; 9(4): 226-231. http://dx.doi.org/10.1016/S0964-3397(05)80003-5

[30] Jun Seongsook, R.N., R.N. Jeong Ihnsook, and R.N. Lee Younghee. Validity of pressure ulcer risk assessment scales; Cubbin and Jackson, Braden, and Douglas scale. International journal of nursing studies. 2004; 41(2): 199-204. http://dx.doi.org/10.1016/S0020-7489(03)00135-4

[31] Kim, E.K., et al. Comparison of the predictive validity among pressure ulcer risk assessment scales for surgical ICU patients. Australian Journal of Advanced Nursing. 2009; 26(4): 87.

[32] de Araujo, T.M., M.F.M. de Araujo, and J.A. Caetano. Comparison of risk assessment scales for pressure ulcers in critically ill patients. ACTA PAULISTA DE ENFERMAGEM. 2011; 24(5): 695-700.

[33] Kottner, J. and T. Dassen, Pressure ulcer risk assessment in critical care: Interrater reliability and validity studies of the Braden and Waterlow scales and subjective ratings in two intensive care units. International journal of nursing studies. 2010; 47(6): 671-677. PMid:20003975 http://dx.doi.org/10.1016/j.ijnurstu.2009.11.005

[34] Feuchtinger, J., R. Halfens, and T. Dassen. Pressure ulcer risk assessment immediately after cardiac surgery-does it make a difference? A comparison of three pressure ulcer risk assessment instruments within a cardiac surgery population. Nursing in Critical Care. 2007; 12(1): 42-49. PMid:17883663 http://dx.doi.org/10.1111/j.1478-5153.2006.00198.x

[35] Sanada, H., et al. Development of a new risk assessment scale for predicting pressure ulcers in an intensive care unit. Nursing in Critical Care. 2008; 13(1): 34-43. PMid:18226053 http://dx.doi.org/10.1111/j.1478-5153.2007.00250.x

[36] Schoonhoven, L., M.T. Bousema, and E. Buskens. The prevalence and incidence of pressure ulcers in hospitalised patients in the Netherlands: a prospective inception cohort study. International journal of nursing studies. 2007; 44(6): 927. PMid:16620820 http://dx.doi.org/10.1016/j.ijnurstu.2006.02.011

[37] Finch, M., Assessment of skin in older people. Nursing Older People. 2003; 15(2): 29. PMid:12715574

[38] Offermanns, S. and W. Rosenthal. Encyclopedia of molecular pharmacology. 2008, New York: Springer Berlin Heidelberg. http://dx.doi.org/10.1007/978-3-540-38918-7

[39] Hagisawa, S. and M. Ferguson-Pell. Evidence supporting the use of two-hourly turning for pressure ulcer prevention. Journal of tissue viability. 2008; 17(3): 76. PMid:18722313 http://dx.doi.org/10.1016/j.jtv.2007.10.001

[40] Goldhill, D., et al. A prospective observational study of ICU patient position and frequency of turning. Anaesthesia. 2008; 63(5): 509-515. PMid:18412649 http://dx.doi.org/10.1111/j.1365-2044.2007.05431.x

[41] Tayyib, N., P. Lewis, and F. Coyer. A Prospective Observational Study of Patient Positioning in A Saudi Intensive Care Unit (Unpublished master's thesis). 2011, Queensland University of Technology Bribane,Australia

[42] Pancorbo-Hidalgo, P.L., et al. Risk assessment scales for pressure ulcer prevention: a systematic review. Journal of advanced nursing. 2006; 54(1): 94-110. PMid:16553695 http://dx.doi.org/10.1111/j.1365-2648.2006.03794.x

[43] Tappen, R.M., Advanced nursing research: from theory to practice. 2011, Sudbury, MA: Jones \& Bartlett Learning.

[44] Burns, N.P.D. and S.K. Grove. The practice of nursing research: conduct, critique, and utilization. 2005, St. Louis, Mo: Elsevier/Saunders.

[45] Polit, D.F. and C.T. Beck, Nursing research: principles and methods. 2004, London: Lippincott Williams \& Wilkins.

[46] Flanagan, M. Who is at Risk of a Pressure Sore: A practical review of risk assessment systems. Professional Nurse. 1995; 10(5): 305-309. PMid:7708787

[47] Defloor, T. and M.F.H. Grypdonck. Validation of pressure ulcer risk assessment scales: a critique. Journal of advanced nursing. 2004; 48(6): 613-621. PMid:15548252 http://dx.doi.org/10.1111/j.1365-2648.2004.03250.x

[48] Scott, E. The prevention of pressure ulcers through risk assessment. Journal of wound care. 2000; 9(2): 69-70. PMid:11933283

[49] Defloor, T. and M.F.H. Grypdonck. Pressure ulcers: validation of two risk assessment scales. Journal of clinical nursing. 2005; 14(3): 373-382. PMid:15707448 http://dx.doi.org/10.1111/j.1365-2702.2004.01058.x

[50] Pender, L.R. and S.K. Frazier. The relationship between dermal pressure ulcers, oxygenation and perfusion in mechanically ventilated patients. Intensive and Critical Care Nursing. 2005; 21(1): 29-38. PMid:15681215 http://dx.doi.org/10.1016/j.iccn.2004.07.005

[51] Webster, J., et al., Validity of the Waterlow scale and risk of pressure injury in acute care. British Journal of Nursing. 2010; 19(6 Suppl): S14-S22. 
[52] European Pressure Ulcer Advisory Panel and National Pressure Ulcer Advisory Panel (EPUAP \& NPUAP). Prevention of Pressure Ulcers: Quick Reference Guide. 2009. Available from: http://www.npuap.org/wp-content/uploads/2012/02/Final_Quick_Prevention_for_web_2010.pdf.

[53] Sanada, H., et al. Risk factors in the development of pressure ulcers in an intensive care unit in Pontianak, Indonesia. International wound journal. 2007; 4(3): 208-215. PMid:17924877 http://dx.doi.org/10.1111/j.1742-481X.2007.00315.x

[54] Shahin, E.S.M., T. Dassen, and R.J.G. Halfens. Incidence, prevention and treatment of pressure ulcers in intensive care patients: a longitudinal study. International journal of nursing studies. 2009; 46(4): 413-421. PMid:18394626 http://dx.doi.org/10.1016/j.ijnurstu.2008.02.011

[55] Moher, D. et al. Preferred reporting items for systematic reviews and meta-analyses: the PRISMA statement. PLoS medicine. 2009; 6(7): e1000097. PMid:19621072 http://dx.doi.org/10.1371/journal.pmed.1000097 